\title{
Physical therapy in the conservative treatment for anterior cruciate ligament rupture followed by contralateral rupture: case report
}

Fisioterapia no tratamento conservador da ruptura do ligamento cruzado anterior seguida por ruptura contralateral: estudo de caso

Fisioterapia en el tratamiento conservador de la ruptura del ligamento cruzado anterior seguida de ruptura contralateral: un estudio de caso

Gabriel Peixoto Leão Almeida', Gilvan de Oliveira Arruda², Amélia Pasqual Marques ${ }^{3}$

\begin{abstract}
I Although the surgical reconstruction be the obvious indication for the anterior cruciate ligament (ACL) lesion, there is no consensus on whether the results of surgery are superior to those obtained with nonsurgical management. The objective of this report was to describe a case of nonsurgical treatment for $\mathrm{ACL}$ rupture followed by a contralateral rupture. A 28-year-old female practitioner of muay-thai and handball suffered a non-contact ACL rupture in the left knee, and three months after the end of rehabilitation, the patient suffered a second non-contact $\mathrm{ACL}$ rupture in the contralateral knee and also received nonsurgical treatment. After both ruptures the patient received a treatment program focused on the strengthening of the quadriceps and hamstring muscles, trunk stabilization, plyometrics exercises, perturbation training, and return-to-sport training. After the treatments the patient exhibited absence of pain; normal muscular function and knee extension and flexion strength; normal range of motion; normal hop tests ( $<10 \%$ difference between members); improvement in the knee functional capacity and total return to normal activities. After two years of follow-up, the patient remained pain free and with normal knee function. The findings demonstrate the physical therapy effects in the nonsurgical treatment of bilateral $\mathrm{ACL}$ rupture. The patient could return to sport practice without instability.
\end{abstract}

Further studies with a larger sample are needed to assess the recovery capacity and the full return to sport activities of patients with $A C L$ injury.

Keywords I Physical Therapy Specialty; Knee; Anterior Cruciate Ligament.

RESUMO I A reconstrução cirúrgica é a indicação mais frequente no tratamento da lesão do ligamento cruzado anterior (LCA). No entanto, não existe consenso de que seus resultados sejam superiores ao tratamento não cirúrgico. Dessa forma, o objetivo deste estudo foi descrever o efeito do tratamento conservador com fisioterapia em um caso de lesão bilateral do LCA em momentos diferentes. Mulher, 28 anos de idade, praticante de muay-thai e handebol, inicialmente sofreu lesão do LCA do joelho esquerdo e três meses depois da alta fisioterapêutica sofreu lesão do LCA contralateral. Nas duas lesões a paciente foi tratada conservadoramente com fisioterapia, com foco no fortalecimento de quadríceps e isquiotibiais, estabilização do tronco, pliometria, treino sensório-motor e, no final, treino de retorno ao esporte. Após os tratamentos, a paciente apresentou ausência de dor, função muscular e amplitude de movimento dos joelhos normais, ausência de instabilidade, testes de salto dentro da normalidade (diferença $<10 \%$ entre os membros), melhora na função do joelho

Study conducted at the Center for Sports Traumatology of the Department of Orthopaedics and Traumatology of the Universidade Federal de São Paulo (UNIFESP) - São Paulo (SP), Brazil.

'Department of Physical Therapy of the Universidade Federal do Ceará - Fortaleza (CE), Brazil.

Instituto Cohen - São Paulo (SP), Brazil.

${ }^{3}$ Department of Physical Therapy, Speech Language Pathology and Audiology and Occupational Therapy of the USP - São Paulo (SP), Brazil. 
e retorno total às atividades que desenvolvia antes das lesões. Após dois anos de seguimento, a paciente permaneceu sem dor e com função normal do joelho. Os achados deste estudo de caso mostram o efeito da fisioterapia no tratamento conservador após a lesão bilateral do LCA, possibilitando o retorno à atividade física desenvolvida antes das lesões. Sugerem-se futuros estudos com amostras maiores para verificar a capacidade de recuperação e o retorno pleno às atividades esportivas dos indivíduos com lesão bilateral do LCA.

Descritores I Fisioterapia; Joelho; Ligamento Cruzado Anterior.

RESUMEN I La reconstrucción quirúrgica es la indicación más frecuente para el tratamiento de la lesión del ligamento cruzado anterior (LCA). Sin embargo, no hay consenso en que sus resultados sean superiores al tratamiento no quirúrgico. Por lo tanto, el objetivo de este estudio fue describir el efecto de un tratamiento conservador con fisioterapia en un caso de lesión bilateral del LCA en diferentes momentos. Mujer, 28 años de edad, practicante de muay-thai y de balonmano, sufrió inicialmente lesión del LCA de la rodilla izquierda y tres meses después del alta de la fisioterapia sufrió lesión del LCA contralateral. En las dos lesiones la paciente fue tratada conservadoramente con fisioterapia, centrándose en el fortalecimiento de los cuádriceps y los isquiotibiales, estabilización del tronco, pliometría, entrenamiento sensoriomotor y , al final, entrenamiento para regreso al deporte. Tras los tratamientos, la paciente presentó ausencia de dolor, función muscular y amplitud de movimiento de la rodilla normales, ausencia de inestabilidad, exámenes de salto dentro de la normalidad (diferencia $<10 \%$ de los miembros), función de la rodilla mejorada y regreso total a las actividades que desarrollaba antes de las lesiónes. Luego de dos años de seguimiento, la paciente permaneció sin dolor y con función normal de la rodilla. Los hallazgos de este estudio de caso muestran el efecto de la fisioterapia en el tratamiento conservador después de la lesión del LCA bilateral, permitiendo el regreso a la actividad física realizada antes de las lesiónes. Se sugieren estudios futuros con muestras más grandes para verificar la recuperabilidad y el regreso pleno a las actividades deportivas de las personas con lesión bilateral del LCA.

Palabras clave I Fisioterapia; Rodilla; Ligamento Cruzado Anterior.

\section{INTRODUCTION}

Approximately $70 \%$ of injuries to the anterior cruciate ligament (ACL) occur without contact, primarily affecting women athletes performing pivot movements, abrupt slowdown, cuts and jumps ${ }^{1}$.

As much as the surgical reconstruction is the obvious indication in these cases, there is no consensus that the intervention is superior to the conservative physical therapy treatment ${ }^{2,3}$. The rate of return to sports is also similar, between 8 and $82 \%$ in patients undergoing surgery and between 19 and $82 \%$ in patients who did not undergo surgical reconstruction ${ }^{4}$.

Currently, there is a considerable effort in order to early identify patients with ACL deficiency (ACLD) who may or may not return to activity without surgery ${ }^{5}$. This classification distinguishes patients with ACL rupture in 3 groups: (1) copers, those who are able to return to their recreational/sports activities without requiring surgery; (2) adapters, those who modify or decrease the level of activity, not requiring surgery then; and (3) noncopers, those who need surgery due to recurrent episodes of knee missteps/giving ways.

Fitzgerald et al. ${ }^{5}$ tested the effectiveness of the treatment algorithm of the University of Delaware to identify those ACLD patients who could benefit from a nonsurgical treatment. They reported that $79 \%$ of those classified as potential copers were able to return to their pre-injury activity level. According to this algorithm, patients with bilateral ACL rupture are indicated for surgery. However, it is unclear whether patients with bilateral lesions at different times may enter the classification examination or if they should be directly reported to surgery.

Thus, the aim of this study was to describe the effect of the conservative physical therapy treatment in a case of bilateral ACL injury at different times.

\section{CASE REPORT}

One female patient, 28 years of age, $1,72 \mathrm{~m}, 62 \mathrm{~kg}$, practitioner of muay-thai and recreational handball, who participates in amateur competitions in both sports, was analyzed. The patient suffered an ACL injury in her left leg and received nonsurgical treatment, after three months of medical discharge the patient suffered a contralateral ACL injury to her right knee, also receiving nonsurgical treatment. Before the injuries, he had not shown significant orthopedic injuries which would require medical treatment or physical therapy. The patient signed the Informed Consent Form. 


\section{History if the first injury}

The patient reported that during a muay thai training, when performing a kick, the body rotated over the base leg (left) supported on the ground and she felt a sharp crack and knee pain. One day after the injury, she sought an orthopedist presenting positive Lachman and anterior drawer tests. On the magnetic resonance imaging (MRI), it was found a complete ACL lesion with thickened and irregular residual fibers together with the intercondyle (Figure 1).

Six days after the injury, she was referred to physical therapy and an evaluation was conducted, with range of motion (ROM) of $96^{\circ}$ for flexion and $-3^{\circ}$ of knee extension, prop degree $3+/ 5$ for knee flexion and 3-/5 for knee extension ${ }^{6}$, knee effusion $2+^{7}$ and 6 points on the visual analogue scale of pain (VAS) ${ }^{8}$.

The initial treatment was performed three times a week for two weeks and consisted of cryotherapy, compression and elevation of the limb to reduce pain and effusion, patellar mobilization and passive exercises to gain ROM for knee extension and flexion, isometric knee extension and flexion at $90^{\circ}$, evolving to resistance exercises with knee extension $\left(90-45^{\circ}\right)$ and knee flexion $\left(0-90^{\circ}\right)$, and also a multidirectional elevation of the leg with extended knee (ELE). After 6 sessions, the patient had ROM of $123^{\circ}$ for flexion and $0^{\circ}$ for knee extension, muscular function $4+/ 5$ degree for flexion and 4-/5 for knee extension, 1.5 points on the

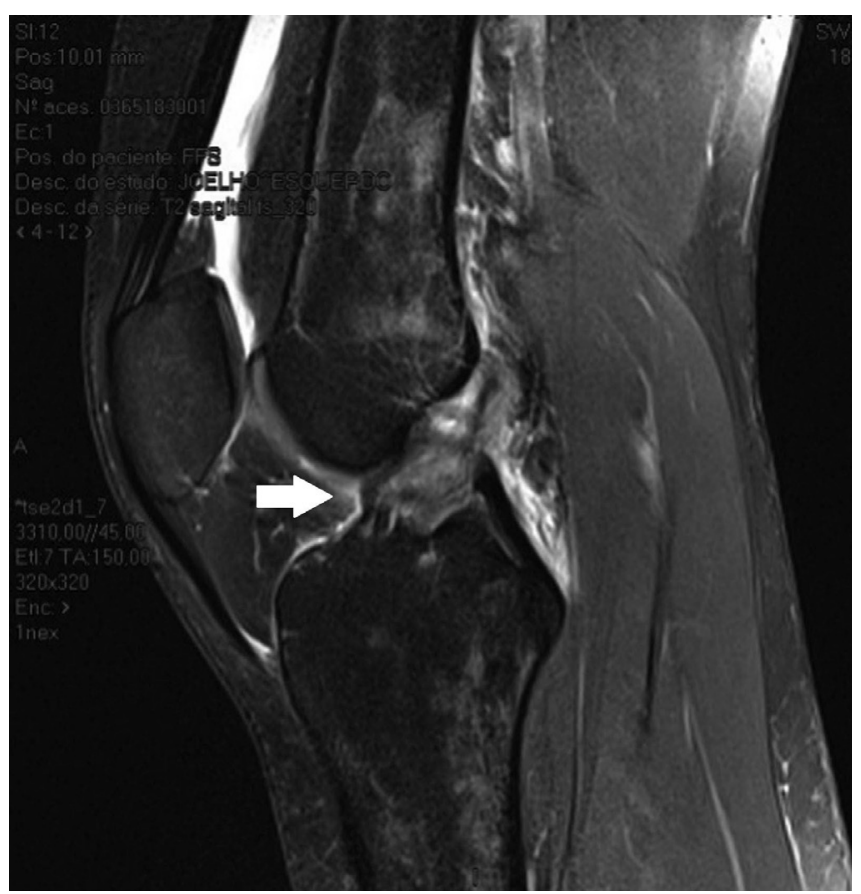

Figure 1. Magnetic resonance imaging in the sagittal plane showing the rupture of the anterior cruciate ligament of the left knee
VAS, with no trace of effusion, normal gait and being able to jump without increasing of the pain. Due to the absence of associated injuries, an assessment was performed in order to classify the patient as a potential coper or noncoper (Table 1). For this, the following tests were performed:

1. Hop tests: 2 jumps for training and 2 jumps for the test were performed ${ }^{9}$. For the simple jump, the patient performed 1 single-leg jump as far as possible; for the triple jump, 3 consecutive single-leg; for the cross jump, 3 consecutive jumps across a 15-cm-thick line on the floor; and for the timed out jump, the patient jumped as quickly as possible until she reached the distance of 6 meters. The symmetry index between the limbs (SIL) was calculated through the following formula: (injured limb/uninjured limb)* 100. Except for the timed jump: (uninjured limb/injured limb)* 100 .

2. Scale of daily living activity (DLA $)^{10}$ : consisting of 14 items with 6 possible answers (0-5 points), assesses symptoms and function related to the knee.

3. Global Knee Function Scale (GKF): assesses the subjective knee function and the score ranges from $0-100 \%, 100 \%$ being the best value possible.

4. Number of episodes of giving way of the knee: when the patient has more than one giving way episode after the injury, they are referred to a surgeon.

Table 1. Pre-and post-treatment assessment after classification rating of the first injury of the anterior cruciate ligament (left knee)

\begin{tabular}{|c|c|c|}
\hline Variables & Pre-treatment & Post-treatment \\
\hline ROM of knee flexion (degrees) & 1230 & 1460 \\
\hline ROM of knee extension (degrees) & $\mathrm{O}^{\circ}$ & $\mathrm{O}^{\circ}$ \\
\hline $\begin{array}{l}\text { Muscle function of knee flexion } \\
(\mathrm{O}-5)\end{array}$ & $4+/ 5$ & $5 / 5$ \\
\hline $\begin{array}{l}\text { Muscle function of knee } \\
\text { extension (O-5) }\end{array}$ & $4-15$ & $5 / 5$ \\
\hline Pain (0-10) & 1,5 & $\mathrm{O}$ \\
\hline Knee effusion (O-3+) & $1+$ & O \\
\hline DLA (0-100) & 90 & 94.2 \\
\hline GKF (0-100) & $70 \%$ & $95 \%$ \\
\hline IKDC (O-100) & 66.67 & 91,95 \\
\hline Lysholm scale (O-100) & 86 & 99 \\
\hline \multicolumn{3}{|l|}{ Hop tests (injuried/not-injured) } \\
\hline Simple hop (m) & 1.48/1.62 (ISM: 91.3\%) & 1.57/1.67 (ISM: 94\%) \\
\hline Triple hop (m) & 4.01/4.51 (ISM: 89.9\%) 4 & 4.48/4.54 (ISM: 98.6\%) \\
\hline Crossed hop (m) & 3.96/4.22 (ISM: 93.8\%) & 4.14/4.26 (ISM: 97.1) \\
\hline Timed hop (seg) & 2.52/2.26 (ISM: 89.6\%) & 2.46/2.29 (ISM: 93.1) \\
\hline
\end{tabular}


The criteria for classification as a potential coper are: $\leq 1$ episode of giving way; timed jump $\geq 80 \%$; $\geq 80 \%$ in DLA; and $\geq 60 \%$ in $\mathrm{GKF}^{5}$. According to these criteria, the patient had a positive result for nonsurgical treatment.

Before starting treatment, the patient underwent other functional assessments and other questionnaires that were applied, including:

1. Subjective questionnaire of the knee by the International Knee Documentation Comittee (IKDC) ${ }^{11}$ : Its result is calculated by summing all items and then being transformed into a scale ranging from $18-100$ points, with 100 points as the best possible score.

2. Lysholm Scale ${ }^{12}$ : consisting of 8 questions, the final result is expressed in nominal and ordinal form, as follows: excellent (95-100 points); good (84-94 points); regular (65-83 points); and poor (below 64 points).

\section{Intervention}

The treatment protocol was performed three times per week, totaling 28 sessions.

In phase $1\left(1^{\text {st }}-10^{\text {th }}\right.$ session $)$, the cardiovascular fitness preparation was performed for 10-20 minutes in a treadmill; strengthening of the hip abductors and adductors, knee flexion and extension, squats, leg press exercises and squat with a single leg, with specifications established in accordance with the American College of Sports Medicine ${ }^{13}$, were performed 3 times per week, totaling 3 series of 6 to 8 repetitions for each exercise. When the patient was able to perform the 3 series and to perform 2 more repetitions in the last two series, the load would be increased between 2 and $10 \%$ for the next session.

A bipedal and single leg plyometric training was conducted by controlling the knee dynamic valgus ${ }^{14}$. In this phase, we also initiated core stabilization exercises with dorsal, lateral and ventral bridges ${ }^{15}$ and sensorimotor training recommended by the University of Delaware ${ }^{16-18}$. This phase consisted of 10 gradually progressed sessions and at the end the patient had no pain and effusion, did not report any episode of giving way and reached maximum muscle function $(5 / 5)$ for flexion and knee extension.

In phase $2\left(11^{\text {th }}-28^{\text {th }}\right.$ session $)$ we continued with the exercises of the first stage and started exercises to return to sports with carioca running (side running by crossing the legs), running with sudden changes of direction, cuts and spins and muay thai kick training. After the $28^{\text {th }}$ session, the patient was performing the exercises with maximum power and agility, being again performed functional tests for the total return to sports (Table 1 ).

\section{History of the second injury}

After three months of medical discharge, the patient ruptured the ACL of the contralateral limb (right one) during a handball match. She reported that during the rotation movement on the right knee she felt a snap, pain and inability to continue playing. She sought for an orthopedic doctor two days after the injury presenting positive Lachman and anterior drawer tests. On the MRI, it was found the complete ACL rupture in the middle third portion, slightly peripheral irregularity of the posterior horn of the medial meniscus without unstable ruptures (Figure 2).

She presented, in the physical therapy assessment, $\mathrm{ROM}$ of $112^{\circ}$ of knee flexion and $0^{\circ}$ of extension, muscle function of $4-/ 5$ degree for knee flexion and $3+/ 5$ for knee extension ${ }^{6}$, knee effusion $1+^{7}$ and 4 points on the $\mathrm{VAS}^{8}$. The patient started physical therapy three days after medical consultation. In the fourth session, the patient presented a ROM of $128^{\circ}$ for knee flexion and $0^{\circ}$ for the extension, muscle function of $4+/ 5$ degrees for knee flexion and $4+/ 5$ for knee extension, no pain, no trace of effusion, normal gait and being able to jump

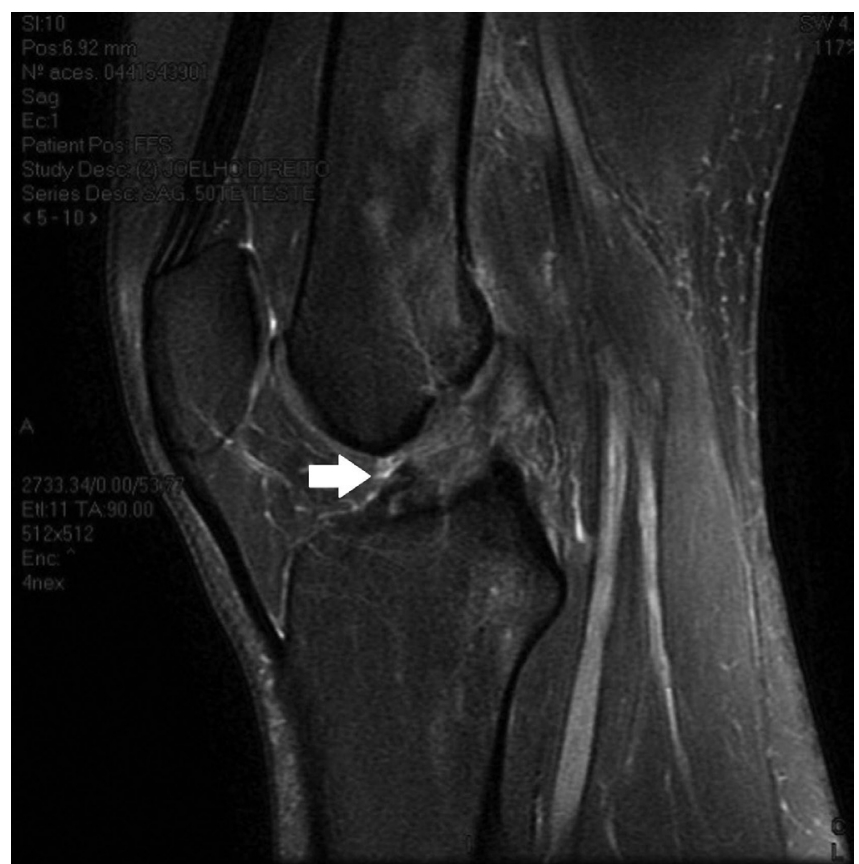

Figure 2. Magnetic resonance imaging in the sagittal plane showing the rupture of the anterior cruciate ligament of the right knee 
without increasing the pain. The examination classification was performed and, according to criteria previously described, she was classified as a potential coper.

The treatment protocol was the same as described above, totaling 23 physical therapy sessions. After phase 1 , the patient remained without pain and episodes of giving way, with normal muscle function for the extension and flexion of the knee (5/5). In phase 2 , there was a shorter rehabilitation time. After the $23^{\text {rd }}$ session, the patient underwent functional tests before returning to sport (Table 2).

\section{RESULTS}

The results of the patient after physical therapy treatment of each ACL injury are shown in Tables 1 and 2 .

In the two injuries, during the rehabilitation process, there were no complications such as effusion, pain or instability. In the first injury, six sessions of pre-classification physical therapy were enough for the patient to meet the requirements to perform classification between being a potential coper or noncoper. In the second injury, it took only four sessions.

After the proposed treatment, there was a normal ROM and muscle function, absence of edema and pain. The hop tests reached an index lower than 10\% and

Table 2. Pre-and post-treatment assessment after classification rating of the first injury of the anterior cruciate ligament (right knee)

\begin{tabular}{|c|c|c|}
\hline & Pre-treatment & Post-treatment \\
\hline ROM of knee flexion (degrees) & 1280 & 1440 \\
\hline $\begin{array}{l}\text { ROM of knee extension } \\
\text { (degrees) }\end{array}$ & $\mathrm{OO}^{\circ}$ & $\mathrm{O}^{\circ}$ \\
\hline $\begin{array}{l}\text { Muscle function of knee } \\
\text { flexion (O-5) }\end{array}$ & $4+/ 5$ & $5 / 5$ \\
\hline $\begin{array}{l}\text { Muscle function of knee } \\
\text { extension }(\mathrm{O}-5)\end{array}$ & $4+/ 5$ & $5 / 5$ \\
\hline Pain (0-10) & 0 & 0 \\
\hline Knee effusion (O-3+) & 0 & 0 \\
\hline DLA (O-100) & 92.85 & 98.5 \\
\hline GKF (O-100) & $80 \%$ & $99 \%$ \\
\hline IKDC (0-100) & 75.86 & 94.5 \\
\hline Lysholm scale (0-100) & 95 & 99 \\
\hline \multicolumn{3}{|l|}{ Hop tests (injuried/not-injured) } \\
\hline Simple hop (m) & 1.42/1.66 (ISM: 85.5\%) & 1.64/1.7 (ISM: 96.5\%) \\
\hline Triple hop (m) & 3.99/4.58 (ISM: 87.1\%) & 4.61/4.65 (ISM: 99.1\%) \\
\hline Crossed hop (m) & 3.87/4.21 (ISM: 90.5\%) & 4.26/4.3 (ISM: 99\%) \\
\hline Timed hop (seg) & 2.75/2.31 (ISM: 84\%) & 2.36/2.23 (ISM: 94.5\%, \\
\hline
\end{tabular}

ROM: range of motion; DLA: scale of daily living activities; GKF: scale of global knee function; IKDC: International Knee Documentation Committee; SIL: Symmetry index between the limbs there has been a considerable improvement in the functional scales of the knee after the treatment for both knees, making the patient able to return to her sports activities (Tables 1 and 2).

\section{The follow up}

After two years of medical discharge the patient was contacted and reported performing all daily and sport activities (weightlifting, Muay Thai and handball) without pain and knee instability. She was asked to answer to the DLA, IKDC and Lysholm scales, presenting the maximum scores on the three scales (100/100).

\section{DISCUSSION}

This case study describes the results of a female athlete who suffered bilateral ACL rupture at different times, obtaining satisfactory results with physical therapy in both lesions. The frequency of contralateral rupture after previous ACL injury occurs in 8.2 to $16 \%$ of the cases ${ }^{19}$.

According to a systematic review of Linko ${ }^{2}$, there is not enough evidence to determine the best treatment, surgical or conservative, in cases of ACL rupture. In the first injury, the patient was sent to perform preoperative physical therapy, however, with the absence of pain, instability and her great progress in physical therapy, the option was by nonsurgical treatment. Due to the good results obtained in the treatment of the first injury, after the second lesion, the patient was referred to our sector, and once again treated without surgery. A clinical trial ${ }^{20}$ comparing rehabilitation with early ACL reconstruction versus rehabilitation with late ACL reconstruction showed no significant difference between groups. However, of the 62 patients who underwent early reconstruction, one did not need to go through the surgery, while out of the $59 \mathrm{pa}-$ tients of late reconstruction, 36 of them did not have to do it. This demonstrates that physical therapy may decrease the need for surgical intervention in patients with ACL injuries.

The first phase of our treatment program was focused on strength training, plyometric exercises, trunk stabilization and sensorimotor training, as proposed by the University of Delaware group for patients classified as potential copers $^{21}$. In the second phase, we added a 
training focused on the return to sports, which require quick changes of direction and cutting and turning movements of the injured knee.

For strength training, we carried out exercises in open and closed kinetic chain with high load and few repetitions, leading to an increase of structural and neuromuscular adaptations ${ }^{22}$. The sensorimotor training is widely used in patients with ACLD and aims to increase the dynamic knee stability, improving the standard of neuromuscular recruitment and normalizing knee kinematics in individuals classified as copers. Fitzgerald et al. ${ }^{16}$ reported that $92 \%$ of potential copers had success after treatment with sensorimotor training against $50 \%$ of potential copers who received treatment without sensorimotor training.

Plyometric exercises increase joint stability and muscle power, being used in various ACL injury preventive programs ${ }^{14}$. The core stability is defined as the ability to control the stem in response to the internal and external disturbances, and studies indicate that increased trunk stability decreases the risk of knee injuries, especially in women ${ }^{23,24}$. The return to sports training allows the patient to gradually experience the game situations, increasing thus the functional ability and confidence of the athlete.

This case study is the first to describe the results of non-surgical treatment for a patient with bilateral ACL injury. Patients with bilateral ACL injury may possibly be included in the classification assessment in order to identify them as copers and thus, do not require surgery. However, these results should be interpreted with caution and not generalized to other patients. Future studies with larger samples may elucidate whether bilateral ACL injuries, either simultaneously or at different times, should be considered an exclusion criterion for classifying a patient as a potential coper. The long-term clinical outcomes of nonoperative treatment of ACL injuries are unknown, so studies with longer follow-up are needed.

\section{CONCLUSION}

The proposed physical therapy treatment made the patient able to return to sports activities at pre-injury level without having to undergo surgery for ACL reconstruction.

\section{REFERENCES}

1. Prodromos CC, Han Y, Rogowski J, Joyce B, Shi K. A meta-analysis of the incidence of anterior cruciate ligament tears as a function of gender, sport, and a knee injury-reduction regimen. Arthroscopy. 2007;23(12):1320-5.

2. Linko E, Harilainen A, Malmivaara A, Seitsalo S. Surgical versus conservative interventions for anterior cruciate ligament ruptures in adults. Cochrane Database Syst Rev. 2005;18(2):CD001356.

3. Delincé P, Ghafil D. Anterior cruciate ligament tears: conservative or surgical treatment? A critical review of the literature. Knee Surg Sports Traumatol Arthrosc. 2012;20(1):48-61.

4. Myklebust G, Bahr R. Return to play guidelines after anterior cruciate ligament surgery. Br J Sports Med. 2005;39(3):127-31.

5. Fitzgerald GK, Axe MJ, Snyder-Mackler L. A decision-making scheme for returning patients to high-level activity with nonoperative treatment after anterior cruciate ligament rupture. Knee Surg Sports Traumatol Arthrosc. 2000;8(2):76-82.

6. Kendall FP, McCreary EK, Provance PG, Rodges MM, Romani WA. Muscles: Testing and function with posture and pain. 5th ed. Baltimore, M.D.: Lippincott, Williams \& Wilkins; 2005.

7. Sturgill LP, Snyder-Mackler L, Manal TJ, Axe MJ. Interrater reliability of a clinical scale to assess knee joint effusion. J Orthop Sports Phys Ther. 2009;39(12):845-9.

8. Flandry F, Hunt JP, Terry GC, Hughston JC. Analysis of subjective knee complaints using visual analog scales. Am J Sports Med. 1991:19(2):112-8.

9. Noyes FR, Barber SD, Mangine RE. Abnormal lower limb symmetry determined by function hop tests after anterior cruciate ligament rupture. Am J Sports Med. 1991;19(5):513-8.

10. Nigri PZ, Peccin MS, Almeida GJM, Cohen M. Tradução, validação e adaptação cultural da escala de atividade de vida diária. Acta Ortop Bras. 2007:15(2):101-4.

11. Metsavaht L, Leporace G, Riberto M, de Mello Sposito MM, Batista LA. Translation and cross-cultural adaptation of the Brazilian version of the International Knee Documentation Committee Subjective Knee Form: validity and reproducibility. Am J Sports Med. 2010;38(9):1894-9.

12. Peccin MS, Ciconelli R, Cohen M. Questionário específico para sintomas do joelho "Lysholm Knee Scoring Scale": tradução e validação para a língua portuguesa. Acta Ortop Bras. 2006:14(5):268-72.

13. American College of Sports Medicine. American College of Sports Medicine position stand. Progression models in resistance training for healthy adults. Med Sci Sports Exerc. 2009;41(3):687-708.

14. Chmielewski TL, Myer GD, Kauffman D, Tillman SM. Plyometric exercise in the rehabilitation of athletes: physiological responses and clinical application. J Orthop Sports Phys Ther. 2006;36(5):308-19.

15. Alentorn-Geli E, Myer GD, Silvers HJ, Samitier G, Romero D, LázaroHaro C, et al. Prevention of non-contact anterior cruciate ligament injuries in soccer players. Part 1: Mechanisms of injury and underlying risk factors. Knee Surg Sports Traumatol Arthrosc. 2009;17(7):705-29.

16. Fitzgerald GK, Axe MJ, Snyder-Mackler $L$. The efficacy of perturbation training in nonoperative anterior cruciate ligament rehabilitation programs for physical active individuals. Phys Ther. 2000;80(2):128-40.

17. Hartigan E, Axe MJ, Snyder-Mackler L. Perturbation training prior to $A C L$ reconstruction improves gait asymmetries in non-copers. J Orthop Res. 2009;27(6):724-9. 
18. Eitzen I, Moksnes H, Snyder-Mackler L, Risberg MA. A progressive 5-week exercise therapy program leads to significant improvement in knee function early after anterior cruciate ligament injury. J Orthop Sports Phys Ther. 2010;40(11):705-21.

19. Wright RW, Magnussen RA, Dunn WR, Spindler KP. Ipsilateral graft and contralateral $A C L$ rupture at five years or more following ACL reconstruction: a systematic review. J Bone Joint Surg Am. 2011;93(12):1159-65

20. Frobell RB, Roos EM, Roos HP, Ranstam J, Lohmander LS. A randomized trial of treatment for acute anterior cruciate ligament tears. N Engl J Med. 2010;363(4):331-42.

21. Chmielewski TL, Hurd WJ, Rudolph KS, Axe MJ, Snyder-Mackler L. Perturbation training improves knee kinematics and reduces muscle co-contraction after complete unilateral anterior cruciate ligament rupture. Phys Ther. 2005;85(8):750-4.

22. Glass R, Waddell J, Hoogenboom B. The effects of open versus closed kinetic chain exercises on patients with ACL deficient or reconstructed knees: a systematic review. N Am J Sports Phys Ther. 2010;5(2):74-84

23. Myer GD, Chu DA, Brent JL, Hewett TE. Trunk and hip control neuromuscular training for the prevention of knee joint injury. Clin Sports Med. 2008;27(3):425-48.

24. Zazulak BT, Hewett TE, Reeves NP, Goldberg B, Cholewicki J. Deficits in neuromuscular control of the trunk predict knee injury risk: a prospective biomechanical-epidemiologic study. Am J Sports Med. 2007;35(7):1123-30. 